\title{
STUDI PERENCANAAN INFRASTRUKTUR DAN UTILITAS DI PULAU PANGGANG, KEPULAUAN SERIBU, DKI JAKARTA
}

\author{
Meyriana Kesuma $^{1}$, Sunaryo Leman ${ }^{2}$, Liong Ju Tjung ${ }^{1}$, Nurmawaddah ${ }^{1}$ \\ ${ }^{1}$ Program Studi Perencanaan Wilayah dan Kota, Universitas Tarumanagara \\ Email: meyrianak @ft.untar.ac.id \\ Email: liongjt@ft.untar.ac.id \\ Email:nurm@ft.untar.ac.id \\ 2 Program Studi Teknik Sipil, Universitas Tarumanagara \\ Email: Sunarjo@ft.untar.ac.id
}

\begin{abstract}
ABSTRAK
Pulau Panggang merupakan salah satu Pulau hunian terpadat di wilayah Kabupaten Administrasi Kepulauan Seribu, DKI Jakarta dimana saat ini pulau tersebut terus mengalami penurunan kualitas lingkungan akibat tingginya kepadatan penduduk yang mencapai 354 jiwa per Ha. Pada kegiatan pengabdian yang dilakukan sebelumnya adalah memberikan usulan alternatif pengembangan kawasan hunian di Pulau Panggang yang mempertimbangkan pertambahan jumlah hunian yang diperlukan selama 20 tahun yang akan datang. Melalui studi sebelumnya, diketahui bahwa penyediaan kawasan hunian perlu diseleraskan dengan penyediaan infrastruktur dan utilitas yang dapat mendukung kegiatan masyarakat sehari-hari. Karena terletak di kepulauan, penyediaan infrastruktur dan utilitas di Pulau Panggang menjadi sulit dan dan terbatas. Sehingga pemahaman mengenai pembangunan infrastruktur yang dapat diaplikasikan di pulau menjadi penting, dan pengetahuan tentang utilitas dasar (air bersih, sampah, listrik, dan drainase) menjadi menjadi penting yang dikaitkan dengan kemajuan teknologi di bidang tersebut. Sehingga studi perencanaan infrastruktur dan utilitas di Pulau Panggang memerlukan studi yang mendalam dan komprehensif serta memerlukan partisipasi dari masyarakat serta berbagai pihak yang terlibat dalam pengembangan Pulau Seribu.
\end{abstract}

Kata kunci: infrastruktur, utilitas, perencanaan kawasan hunian

\section{PENDAHULUAN}

Pulau Panggang yang berlokasi di Kabupaten Administrasi Kepulauan Seribu telah menjadi salah satu lokasi Pengabdian kepada Masyarakat yang dilakukan oleh Prodi Perencaaan Kota dan Real Estat Universitas Tarumanagara sejak tahun 2016. Bekerjasama dengan Ikatan Alumni Perencanaan Kota dan Real Estat Universitas Tarumanagara, Community for Maritime Studies Indonesia (CMSI) dan Pemerintah Kabupaten Administrasi Kepulauan Seribu, kegiatan Pengabdian Masyarakat dilakukan bersama-sama secara bertahap, dari mulai melakukan studi identifikasi permasalahan, studi penataan kawasan hunian di Pulau Panggang, studi potensi ekonomi dan pariwisata di Pulau Panggang, termasuk diantaranya Studi Infrastruktur dan Utilitas di Pulau Panggang ini.

Dengan tingginya minat penduduk untuk tinggal di Pulau Panggang menyebabkan kebutuhan akan hunian di Pulau Panggang sangat tinggi, yang terlihat dari adanya penambahan lahan seluas $3 \mathrm{Ha}$ di Pulau Panggang yang dilakukan secara mandiri oleh masyarakat dengan cara menimbun sampah. Dengan adanya kondisi reklamasi mandiri yang dilakukan oleh masyarakat dengan menggunakan sampah, menunjukkan bahwa kesadaran masyarakat akan lingkungan masih rendah, sehingga perlu dukungan dari berbagai pihak untuk membuat masyarakat Pulau Panggang dapat mencintai dan menghargai pulaunya sebagai satu lingkungan ekosistem yang ramah lingkungan. Hal lainnya adalah untuk menjadi keberlanjutan dari keberadaan sebuah pulau, pulau tersebut harus dapat mengolah sampah yang dihasilkannya sendiri (zero waste).

Kondisi lainnya yang terjadi di Pulau Panggang adalah tidak adanya jalan lingkar yang menyambungkan pulau dari sisi utara ke selatan dan timur ke barat sehingga sirkulasi masyarakat 
menjadi terbatas dan tidak efektif (karena harus menggunakan motor atau sepeda untuk menghemat tenaga dan waktu). Infrastruktur dan utilitas menjadi sangat vital untuk keberlanjutan sebuah pulau kecil. Hal ini juga menjadi dasar untuk perencanaan dan revitalisasi pulau sehingga kawasan hunian dapat memiliki lingkungan yang nyaman dan layak huni.

\section{METODE PELAKSANAAN PKM}

Untuk melakukan studi infrastruktur \& utilitas diperlukan pemetaan (mapping) yang detil untuk melihat kondisi jalan dimana saat ini jalan di pulau panggang belum tersambung dengan lebar jalan yang berbeda-beda. Untuk Pengabdian Kepada Masyarakat yang dilaksanakan di Pulau Panggang Kepulauan Seribu DKI Jakarta adalah untuk membantu Pemda setempat dalam melakukan penataan hunian warga Pulau Panggang yang saat ini sangat dibutuhkan. Sementara salah satu teknik untuk pendataan lahan berupa lokasi perumahan, jalan akses dan kemungkinan lainnya diperlukan citra gambar Pulau Panggang yang terbaru.

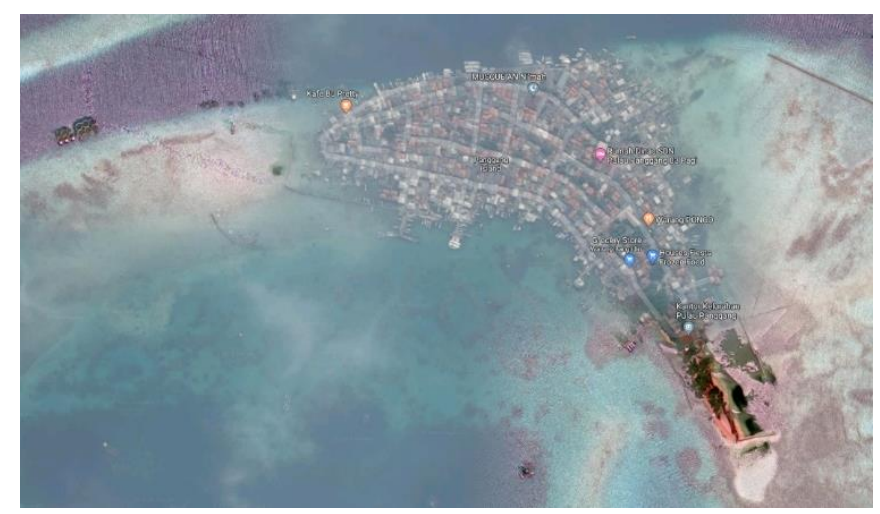

Gambar 1. Hasil dari pencitraan Google Maps

Sumber: Google Maps, 2018

Karena hasil yang tidak memadai, maka untuk memperoleh data yang terbarukan dicoba dengan menggunakan pencitraan gambar menggunakan Drone yang dianggap lebih murah dari segi biaya dibandingkan dengan menggunakan pencitraan satelit. Teknik dalam pengambilan gambar dilakukan dengan cara menaikan Drone sampai ketinggian tertentu dan melakukan pemotretan dengan sudut tegak lurus permukaan bumi yang mau diambil gambarnya. Apabila pengambilan gambar tidak dapat mencakup semuanya karena keterbatasan tinggi terbang Drone yang diijinkan maka dilakukan dengan metode berikutnya yaitu pengambilan gambar dengan teknik overlay atau Stepping Zone.

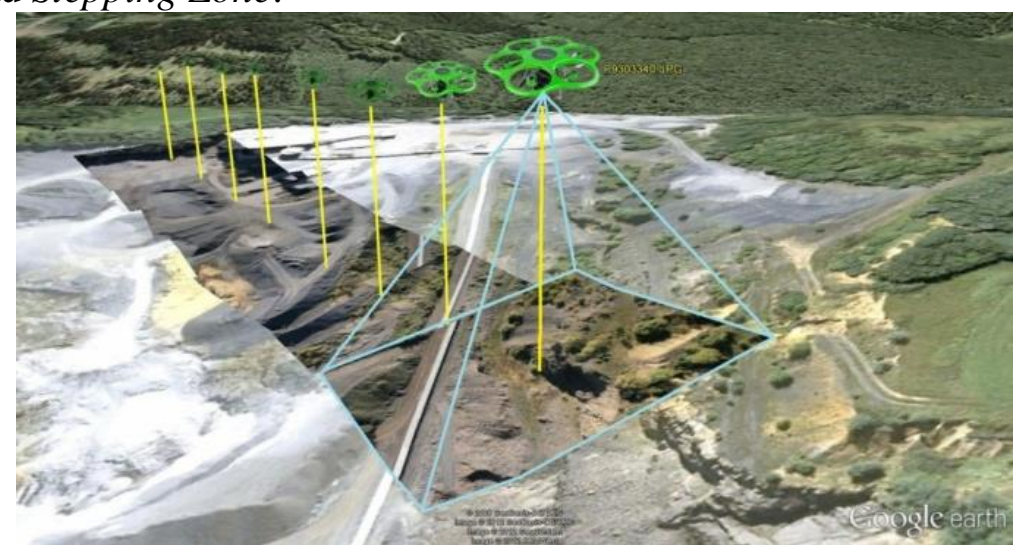

Gambar 2. Proses pengambilan foto dengan drone (Stitching/ Stepping Zone Technic)

Sumber : (https://airdronesia.blogspot.com/) 
Setelah proses pengambilam foto dengan menggunakan teknik Stitching, maka diperlukan proses selanjutnya berupa post processing penggabungan foto-foto tersebut dengan menggunakan teknik Overlay/ Stacking dengan menggunakan software pengolah gambar digital.

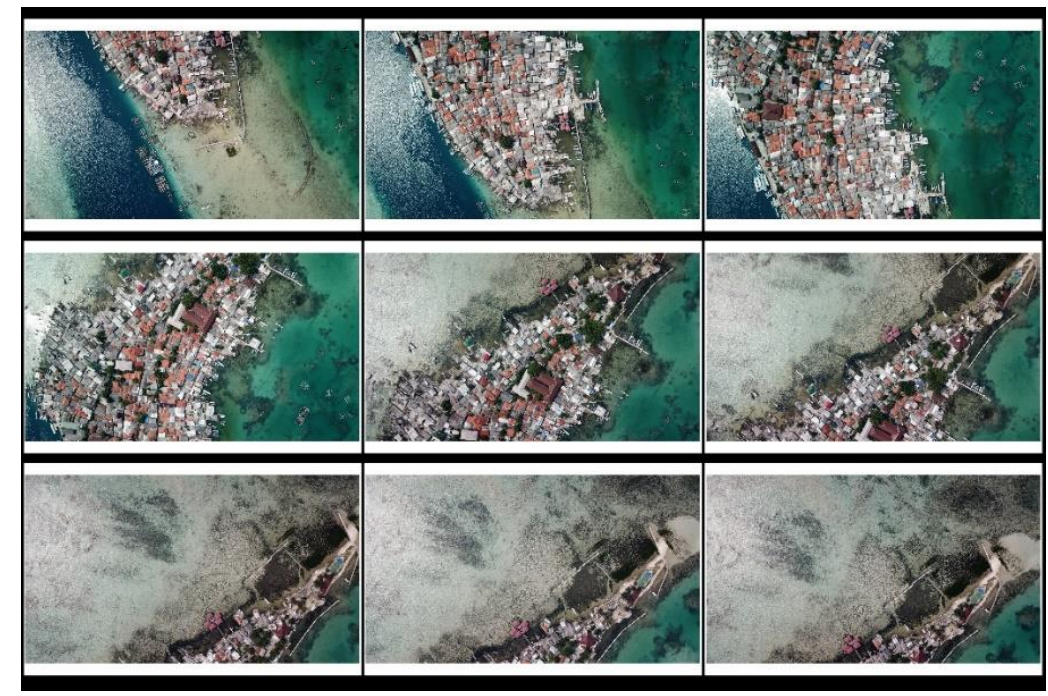

Gambar 3. Stitching Foto Pulau Panggang

Sumber: Dokumentasi Tim PKM PWK-RE Untar, 2018

Hasil yang diperoleh dengan teknik Stitching dan pengolahan post processing Overlay diperoleh hasil yang sangat baik dan merupakan hasil foto pencitraan yang terbaru. Dari hasil pemetaan tersebut, dapat terlihat dengan jelas, kondisi jalan yang tidak tersambung dan mengalami penyempitan di beberapa area, dimana hal ini dapat mempengaruhi struktur utilitas yang ada di dalam kawasan hunian di pulau panggang tersebut. Berikut adalah hasil foto citras satelit yang digunakan sebagai peta identifikasi infrastruktur di Pulau Panggang.

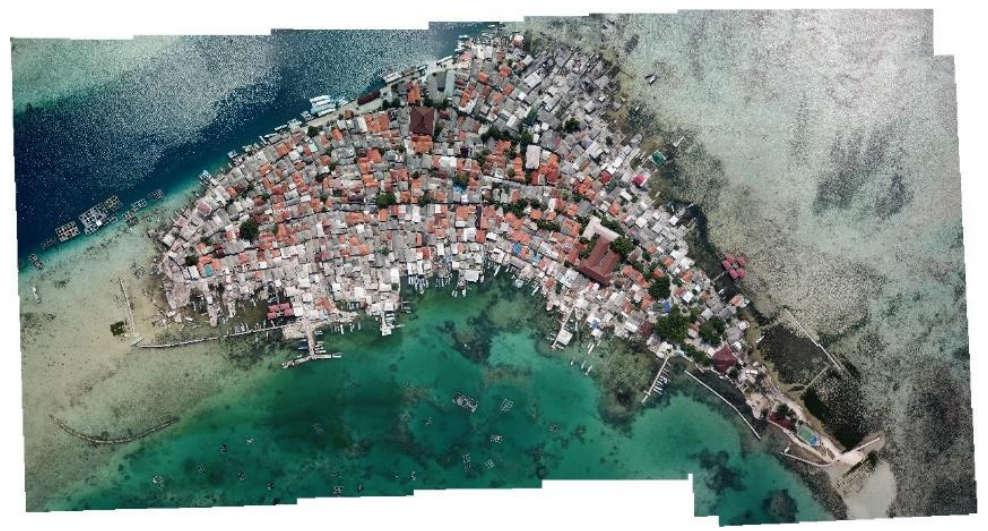

Gambar 4. Hasil Pengolahan Teknik Overlay/ Stacking Sumber: Dokumentasi Tim PKM PWK-RE Untar, 2018

Sementara, untuk metode analisis infrastruktur \& utilitas dilakukan dengan mengacu pada peraturan dan standar terkait dengan perencanaan sarana dan prasarana di kawasan permukiman, dimana dalam hal ini beberapa peraturan yang akan diambil sebagai acuan dalam menghitung kebutuhan infrastruktur \& utilitas di kawasan permukiman :

1. Infrastruktur Jalan menggunakan Pedoman Teknis Prasarana Jalan Perumahan (Sistem Jaringan dan Geometri Jalan), Dirjen Cipta Karya, 1998. 
2. Jaringan Drainase menggunakan SNI 02-2406-1991 tentang Tata cara perencanaan umum drainase perkotaan.

3. Untuk standar jaringan air bersih, terdapat beberapa acuan pedoman, yaitu :

- SNI 03-2399-1991 tentang Tata Cara Perencanaan Bangunan MCK Umum.

- SNI 03-1745-1989 tentang Tata Cara Pemasangan Sistem Hidran Untuk Pencegahan Bahaya Kebakaran Pada Bangunan Rumah dan Gedung.

4. Untuk jaringan air limbah, dapat mengacu kepada adalah SNI-03-2398-2002 tentang Tata Cara Perencanaan Tangki Septik dengan Sistem Resapan, serta pedoman tentang pengelolaan air limbah secara komunal pada lingkungan perumahan yang berlaku.

5. Lingkungan perumahan harus dilengkapi perencanaan penyediaan jaringan listrik sesuai ketentuan dan persyaratan teknis yang mengacu pada standar berikut :

- SNI 04-6267.601-2002 tentang Istilah kelistrikan (Bab 601: Pembangkitan, Penyaluran dan Pendistribusian Tenaga Listrik - Umum);

- $\quad$ SNI 04-8287.602-2002 tentang Istilah kelistrikan (Bab 602: Pembangkitan); dan

- SNI 04-8287.603-2002 tentang Istilah kelistrikan (Bab 603: Pembangkitan, Penyaluran dan Pendistribusian Tenaga Listrik - Perencanaan dan Manajemen Sistem Tenaga Listrik)

6. Lingkungan perumahan harus dilayani sistem persampahan yang mengacu pada:

- SNI 19-2454-2002 tentang Tata cara teknik operasional pengolahan sampah perkotaan;

- SNI 03-3242-1994 tentang Tata cara pengelolaan sampah di permukiman; dan

- SNI 03-3241-1994 tentang Tata cara pemilihan lokasi tempat pembuangan akhir sampah.

\section{HASIL DAN PEMBAHASAN}

Dalam studi infrastruktur \& utilitas di pulau panggang dilakukan beberapa analisis, mulai dari analisis kondisi eksisting infrastruktur dan utilitas sampai dengan analisis perhitungan kebutuhan yang dihitung berdasarkan Standar Nasional Indonesia (SNI) dimana salah satu kelemahan untuk perencanaan infrastruktur dan utilitas pada Pulau Kecil di Indonesia adalah belum adanya standar yang sesuai dengan karakteristik pulau-pulau kecil, sehingga perhitungan standar perlu dilakukan adjustment sesuai dengan kondisi dan karakteristik masing-masing pulau.

\section{A. Analisis Kondisi Infrastruktur di Pulau Panggang}

Pulau Panggang memiliki luas 9 Ha dimana didukung dengan transportasi jalan dengan kelas lokal. Tipe jalan yang terdapat di Pulau Panggang adalah jalan lokal yang mayoritas memiliki ROW (Right of Way) sebesar 2 meter dan tidak memiliki bantaran atau Garis Sempadan Jalan yang menyebabkan rumah langsung berbatasan dengan jalan. Hal ini menyebabkan sebagian besar jalan tertutup oleh bayangan bangunan sehingga jalan tetap adem pada siang hari sekalipun. Pada satu sisi cukup baik, karena membuat masyarakat nyaman berjalan kaki di dalalm pulau, namun dalam sisi yang lain juga menyebabkan dampak yang kurang baik bagi masyarakat, terutama sirkulasi udara di Pulau Panggang. Dimana sirkulasi udara yang kurang baik telah menimbulkan dampak yang berdasarkan hasil wawancara, mayoritas penyakit yang diderita oleh masyarakat Pulau Panggang adalah penyakit ISPA.

Selain kondisi di atas, dengan kepadatan penduduk yang sangat tinggi di Pulau Panggang menyebabkan hampir tidak ada ruang terbuka lagi yang dapat ditemukan, dimana ruang terbuka biasanya sudah berubah menjadi bangunan rumah. Hal tersebut menyebabkan keterbatasan dari ruang terbuka yang ada dan seringkali jalan pun dijadikan sarana bersosialisasi oleh warga sehingga seringkali kegiatan warga sering terlihat terjadi di jalan dan menutupi sebagian jalan. 


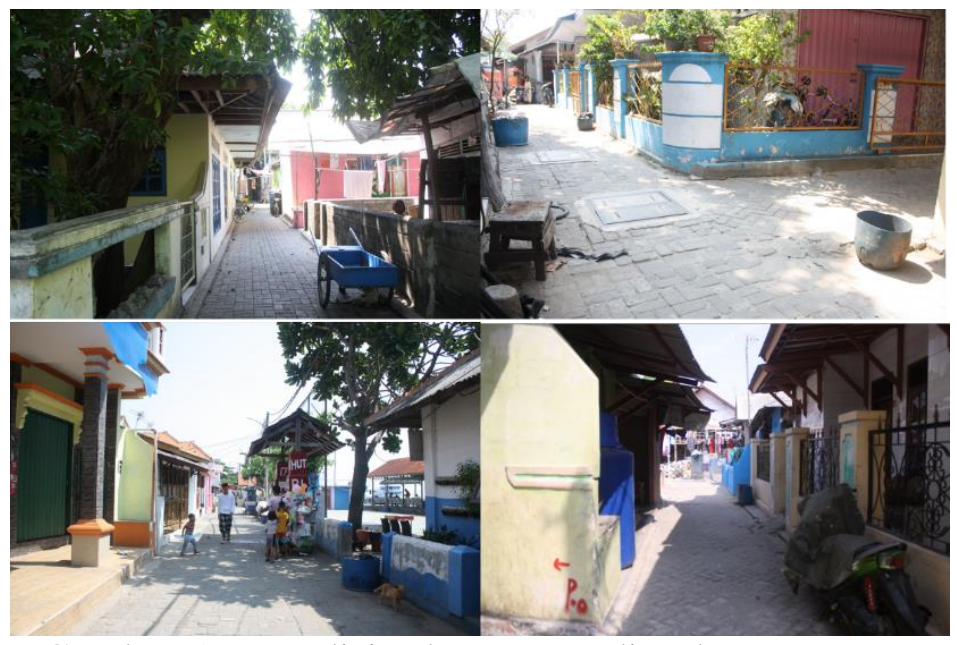

Gambar 5a. Kondisi Jalan Utama di Pulau Panggang Sumber: Hasil Survei Tim, 2017

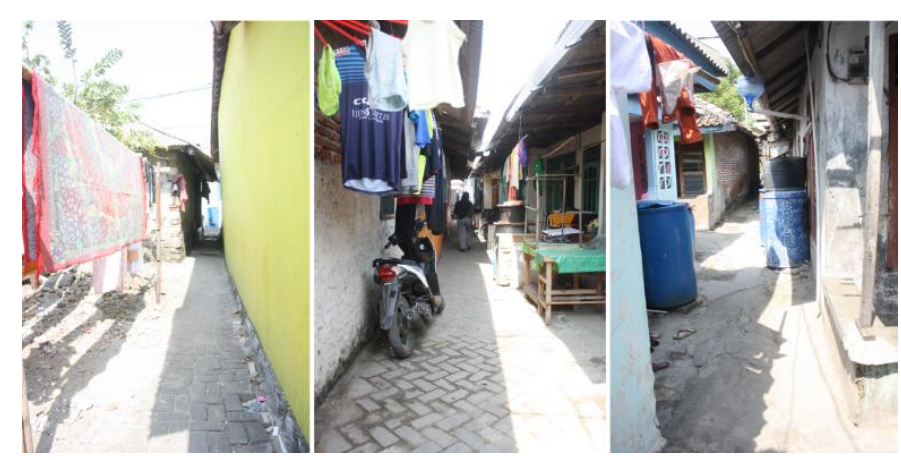

Gambar 5b. Kondisi Jalan gang di Pulau Panggang Sumber: Hasil Survei Tim, 2017

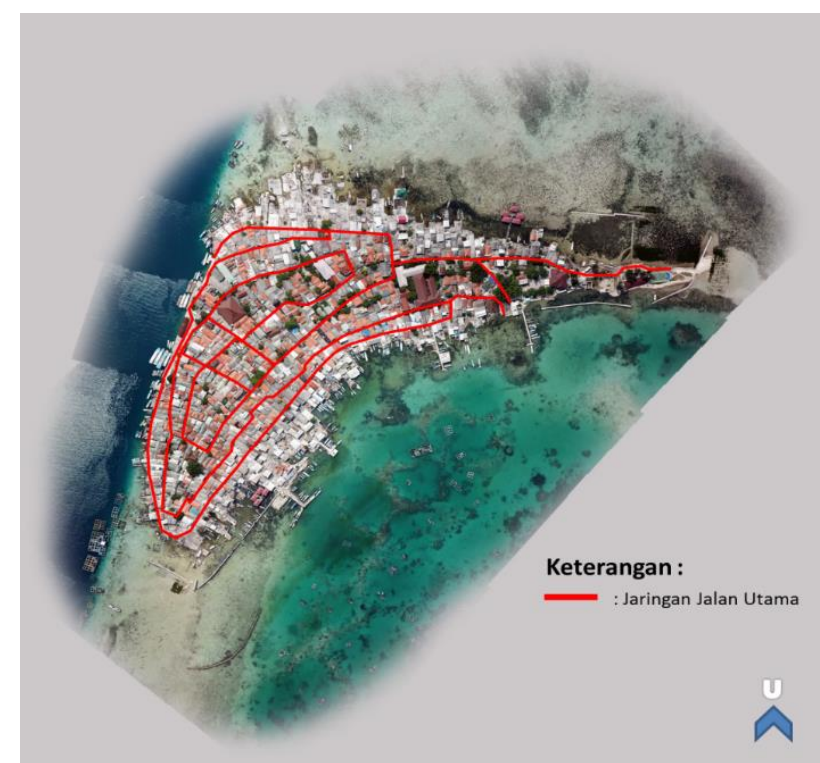

Gambar 6. Jaringan Jalan Utama di Pulau Panggang Sumber: Hasil Survei Tim, 2018

Sepeda motor adalah moda transportasi yang umum digunakan oleh warga Pulau Panggang untuk mobilisasi di dalam pulau, terutama oleh masyarakat yang tidak menjalankan bisnis perdagangan. 
Sedangkan untuk masyarakat yang membuka usaha, bentor (becak motor - motor yang memiliki ruang di belakangnya) merupakan moda transportasi yang paling sering digunakan untuk mengangkut barang.

Dengan lebar jalan yang hanya 2 meter menyebabkan jika ada 2 motor yang melalui jalan dengan arah yang berbeda masih bisa dilalui. Namun jika dilalui oleh bentor, maka sepeda motor maupun pejalan kaki harus berhenti dan menyingkir ke tepi jalan sehingga bentor dapat melalui jalan tersebut dengan lancar.

Permasalahan infrasrtuktur lainnya di Pulau Panggang adalah tidak adanya jalan lingkar yang memutari sisi terluar pulau, sehingga untuk dapat menjangkau pulau sebelah barat dari arah timur, masyarakat harus kembali ke pusat terlebih dahulu ataupun sebaliknya. Dengan demikian, mobilitas maupun sirkulasi orang dan kendaraan di Pulau Panggang menjadi tidak efektif.

\section{B. Analisis Kondisi Utilitas di Pulau Panggang}

Utilitas sangat berkaitan erat dengan infrasrtuktur. Penyediaan utilitas di sebuah pulau kecil menjadi tantangann tersediri, dimana pulau diharapkan dapat secara mandiri menyediakan dan melayani kebutuhan masyarakat akan utilitas dasar. Yang dimaksud dengan utilitas dasar adalah air bersih, listrik, drainase, dan sampah.

\section{Air Bersih}

Air bersih merupakan kebutuhan dasar hidup manusia yang sangat diperlukan untuk hampir seluruh kegiatan manusia (masak, mandi, cuci, dan sebagainya). Untuk itu, penyediaan air bersih menjadi salah satu hal yang sangat diperhatikan oleh pemerintah kabupaten. Untuk memenuhi kebutuhan air bersih warga, pemerintah menyediakan SWRO (Sea Water Reverse Osmosis) yang terletak di Pulau Karya (yang merupakan pulau tak berpenghuni dan tertelak di sebelah Pulau Panggang). Namun, kapasitas produksi sebesar 90 liter per hari per orang dengan hitungan jumlah penduduk pada tahun 2015. Namun, karena kebutuhan air per hari per orang di Pulau Panggang lebih dari 90 liter, maka mayoritas warga masih menggunakan air tanah (yang tentu saja payau) dan tampungan air hujan untuk dapat memenuhi kebutuhan air bersih.

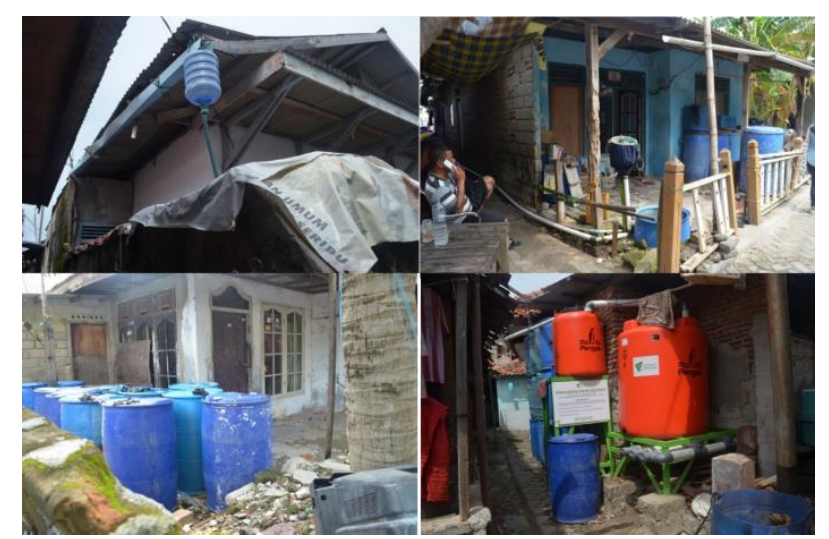

Gambar 7. Penampungan Air Hujan di Rumah Warga Sumber: Hasil Survei, 2018

\section{Listrik}

Pemenuhan listrik di Pulau Panggang awalnya menggunakan Pembangkit Listrik Tenaga Diesel (PLTD) dan mulai tahun 2014 PLN (Perusahaan Listrik Negara) mulai masuk ke Kepulauan Seribu, termasuk Pulau Panggang, yang menggunakan optic jaringan bawah laut dengan sumber energi dari Jakarta. Sampai saat ini, pelayanan penyediaan listrik di Pulau Panggang sudah hampir 
memenuhi $100 \%$, dimana sebagai pendukung, masyarakat tetap menyimpan diesel. Melalui data yang diperoleh terkait dengan pemenuhan energi listrik yang ada di Pulau Panggang, dapat dikatakan bahwa listrik sudah tidak menjadi masalah bagi masyarakat Pulau Panggang.

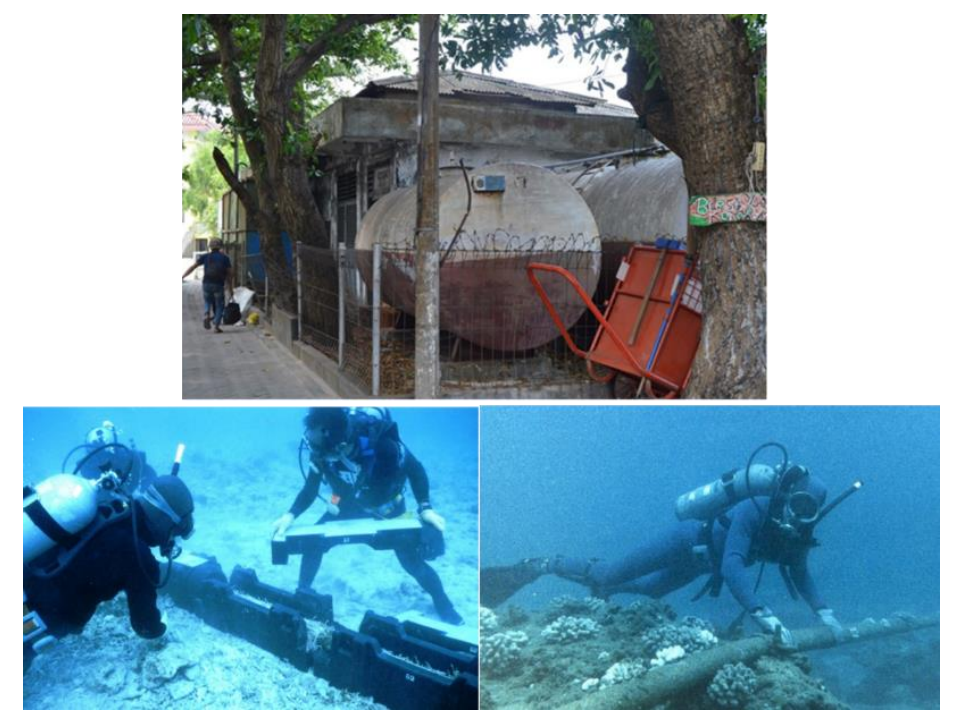

Gambar 8. Pembangkit Listrik Tenaga Diesel yang ada di Pulau Panggang Sumber: Hasil Survei, 2018

\section{Drainase}

Drainase merupakan salah satu prasarana dasar untuk pemenuhan kebutuhan dasar kehidupan manusia. Dengan drainase yang baik, diharapkan dapat meningkatkan kualitas hidup masyarakat sekitarnya, dengan mengurangi resiko munculnya penyakit melalui lingkungan yang tidak sehat. Drainase seringkali menjadi permasalahan di kehidupan perkotaan, termasuk Jakarta. Jika Jakarta dengan luas lahan yang dimilikinya, masih memiliki masalah drainase yang perlu dipecahkan bersama, anggapan dari kondisi drainase di pulau kecil akan memiliki masalah yang serupa.

Pulau Panggang berdiri di atas pasir dan karang, sehingga kemampuannya untuk menyerap air tinggi. Selain itu, jalan yang ada di Pulau Panggang menggunakan konblok, sehingga penyerapan air di jalan juga mudah. Dengan demikian, jika air buangan dari hujan dan limbah cair rumah tangga, tidak menjadi masalah. Yang menjadi permasalahan adalah limbah cair yang berasal dari toilet.

Pulau Panggang memiliki 1 IPAL, namun sudah tidak bisa beroperasi secara maksimal, karena ada kerusakan komponen yang belum diselesaikan hingga saat ini. Selain itu, aliran drainase mengikuti jalan dimana aliran air kotor mengalir melalui selokan yang saat ini memiliki sistem tertutup dikarenakan lebar jalan yang sangat kecil.

\section{Sampah}

Sampah menjadi masalah utama perkotaan dimanapun di Indonesia. Saat kita belum bisa mengolah sampah yang kita hasilkan sendiri, hal itu menjadi masalah, karena sampah itu akan menjadi beban bagi kota. Sama halnya dengan sampah di pulau kecil. Dengan lokasi pulau kecil, yang biasanya memeiliki masalah transportasi dan mobilitas dengan daratan dan pulau kecil lainnya, sampah menjadi hal yang perlu diperhatikan.

Dengan permasalahan yang ada telah menurunkan kemampuan Pulau Panggang untuk mengolah sampahnya sendiri. Adapun perlu diketahui juga, bahwa abu hasil pembakaran sampah di 
incinerator dimanfaatkan masyarakat untuk melakukan reklamasi secara mandiri, dimana tanah yang dihasilkan dari reklamasi mandiri tersebut digunakan untuk membangun hunian.

\section{Analisis Standar Kebutuhan Utilitas di Pulau Panggang}

Pada analisis ini dijelaskan mengenai Standar kebutuhan utilitas di Pulau Panggang yang sesuai dengan Standar Nasional Indonesia (SNI) mengenai standar prasarana di perkotaan. Berikut hasil perhitungan standar kebutuhan utilitas di Pulau Panggang :

\section{Air Bersih}

Analisis kebutuhan air bersih sangat diperlukan untuk mengetahui seberapa besar kapasitas yang diperlukan sesuai dengan jumlah penduduk pulau panggang dimasa yang akan mendatang. Sebelum melakukan perhitungan kebutuhan air bersih dengan menggunakan standart perhitungan yang telah ditetapkan, tim PKM Untar melakukan tes uji air dimana diambil sampel air dari 2 (dua) lokasi yaitu di sekolah SDN Pulau Panggang dan dipinggir Pulau Panggang. Hasilnya air yang ada di Pulau Panggang sudah sangat asin, dimana air yang berada di dalam sekolah, rasa asinnya sudah menyamai dengan air yang berada dipinggir Pulau. Hal ini menyebabkan, warga menggunakan air galon untuk konsumsi minum, sementara air tanah hanya dipakai untuk mencuci piring (sebagian warga menggunakan air tanah untuk mencuci baju).

Faktor utama dalam analisis kebutuhan air adalah jumlah penduduk pada daerah studi. Pada studi sebelumnya telah dihitung proyeksi jumlah penduduk di Pulau Panggang sampai dengan tahun 2027 sebanyak 4.825 jiwa. Dari proyeksi tersebut, kemudian dihitung jumlah kebutuhan air berdasarkan kriteria Ditjen Cipta Karya 1996. Menurut Standar Nasional Indonesia (SNI), pemakaian air bersih pada domestik pemipaan khususnya sambungan rumah adalah 120 liter/orang/ hari maka dapat diasumsikan kebutuhan air bersih di Pulau Panggang pada tahun 2027 sebagai berikut :

$\rightarrow$ Jumlah Penduduk x sambungan 150 liter/jiwa/hari

\subsection{5 jiwa $x 150$ liter/jiwa/hari $=723.750$ jiwa per hari $\approx 724 \mathrm{~m} 3 /$ hari}

\section{Listrik}

Meskipun kebutuhan listrik sudah cukup terpenuhi di Pulau Panggang, tetapi perlu dilakukan perhitungan kebutuhan untuk 10 tahun yang akan datang dimana proyeksi penduduk 10 tahun (tahun 2027) jumlah penduduk pulau panggang akan terus bertambah dan juga perlu dilakukan perhitungan untuk proyeksi kebutuhan listrik jika akan dikembangkan hunian baru di Pulau Panggang sebagai bagian dari penataan kawasan hunian di pulau panggang serta pengembangan kawasan ekonomi pariwisata pulau panggang. Untuk rencana pengembangan kawasan hunian di Pulau Panggang, dimana kebutuhan sampai dengan tahun 2027 adalah sebanyak 123 unit rumah ditambah dengan unit hunian pengganti hunian lama yang akan dilakukan dengan cara konsolidasi lahan, diperkirakan sebanyak 242 unit sehingga total hunian yang akan dikembangkan sebanyak 365 unit hunian dimana luas bangunan unit hunian direncanakan sebesar $36 \mathrm{~m} 2$ dan $48 \mathrm{~m} 2$. Perhitungan kebutuhan listrik untuk hunian dilakukan dengan menggunkan standar SNI. Berikut adalah perhitungan listrik untuk rencana pengembangan hunian di pulau panggang.

$\rightarrow$ Perumahan dengan golongan tipe A (Rumah kecil) : $450 \mathrm{VA} / \mathrm{Watt}$

Maka Kebutuhan listrik untuk 365 unit hunian sebesar :

365 unit $\mathrm{x} 450 \mathrm{VA} / \mathrm{Watt}=\mathbf{1 6 4 . 2 5 0} \mathrm{VA} / \mathrm{Watt}$

$\rightarrow$ Selain itu, perlu juga dihitung kebutuhan listrik untuk fasilitas dan area komersial jika akan dilakukan pengembangan kawasan ekonomi dan wisata di pulau panggang. Dimana direncakan 
akan terdapat pusat jajan serba ikan dan pusat kuliner serta terdapat fasilitas seperti Mushola dan Taman. Berikut adalah perhitungan kebutuhan listriknya :

- Fasilitas perdagangan, standar suplai energi listriknya sebesar 25\% dari kebutuhan Rumah Tangga (RT) :

164.250 VA/Watt x $25 \%=41.062 \mathrm{VA} / \mathrm{Watt}$

- Fasilitas sosial dan pelayanan umum serta fasilitas kesehatan, pendidikan, dan peribadatan, standar suplai energi listrik sebesar 25\% dari kebutuhan RT.

164.250 VA/Watt x 25\% $=41.062 \mathrm{VA} / \mathrm{Watt}$

- Penerangan jalan membutuhkan $10 \%$ energi listrik dari total kebutuhan RT.

164.250 VA/Watt x $10 \%=16.425 \mathrm{VA} / \mathrm{Watt}$

Total kebutuhan listrik untuk fasilitas dan komersial sebesar : 98.550 VA/Watt

\section{Air Limbah}

Berdasarkan acuan studi JICA 1990 (proyeksi 2010), standar air limbah dari rumah biasa (sebagai rata-rata) menghasilkan air limbah atau buangan sebanyak 120 liter/orang/hari. Maka, air limbah yang akan dihasilkan penduduk Pulau Panggang diperhitungkan sebagai berikut:

$\rightarrow$ Jumlah penduduk Pulau Panggang tahun 2027 sebanyak 4.825 jiwa 4.825 jiwa $x 120$ liter/jiwa $=\mathbf{5 7 9 . 0 0 0 ~ l i t e r} / \mathbf{h a r i} \approx \mathbf{5 7 9} \mathbf{~} \mathbf{3} / \mathbf{h a r i}$

$\rightarrow$ Perlu dilakukan perbaikan alur drainase seiring dengan rencana pengembangan jalan lingkar luar Pulau sehingga menjadi sistem drainase utama dengan kapasitas yang lebih besar dan dengan sistem tertutup.

\section{Sampah}

Saat ini di Pulau Panggang hanya mengandalkan 1 incinerator untuk mengolah sampah. TPS ataupun dipo untuk pengumpulan sampah sementara belum tersedia di Pulau Panggang, hal ini juga terkait dengan lahan untuk TPA ataupun dipo. Untuk rencana pengembangan kawasan hunian di Pulau Panggang dimana pada tahun 2027 akan direncanakan penambahan unit hunian sebanyak 365 unit, maka perlu dilakukan perhitungan kebutuhan dipo atau TPS ataupun incinerator untuk menampung sampah rumah tangga dari unit hunian yang baru.

$\rightarrow$ Di asumsikan setiap $1000 \mathrm{KK}$ menghasilkan sampah sebanyak $8 \mathrm{~m} 3$ (Permen PU) dan jumlah KK di pulau panggang tahun 2027 sebanyak $1.207 \mathrm{kk}$, maka estimasi perhitungan volume sampah di Pulau Panggang adalah sebagai berikut :

Volume Sampah $=1.207 \mathrm{KK} / 1.000 \mathrm{KK}$ x $8 \mathrm{~m} 3=\mathbf{9 , 6} \mathbf{~ m 3}$ per hari

$\rightarrow$ Incinerator yang dimiliki oleh Pulau Panggang saat ini berkapasitas 1,5 Ton sampah. Dengan jumlah volume sampah pada tahun 2027 sebesar 9,6 m3 per hari maka incinerator yang ada saat ini di Pulau Panggang masih memadai. Tetapi perlu dipikirkan kualitas dan teknologi daripada insinerator eksisting, apakah masih memadai atau tidak

\section{KESIMPULAN \& SARAN}

Kesimpulan yang dapat diperoleh dari Studi Infrastruktur dan Utilitas pada kegiatan Pengabdian Kepada Masyarakat ini adalah:

1. Perlunya standar untuk infrastruktur dan Utilitas di hunian padat di Pulau kecil seperti Pulau Panggang sehingga standar kebutuhan akan infrastruktur dan utilitas dapat terpenuhi sehingga dapat menunjang kehidupan masyarakat untuk hidup lebih layak.

2. Masalah Infrastruktur (tidak terhubungnya jalan utama dan tidak adanya hirarki jalan akibat kondisi hunian di pulau panggang yang sangat padat) menjadi hal yang utama untuk diselesaikan. Terkait juga dengan rencana pengembangan hunian baru di Pulau Panggang, diharapkan pengembangan infrastruktur jalan dapat dikembangkan secara bersamaan 
3. Untuk utilitas, perlu difokuskan kepada Air Bersih, dimana saat ini air bersih menjadi isu utama di pulau panggang. Saat ini, Pemerintah Kabupaten Administrasi Pulau Panggang sedang mengusahakan pengadaan alat Reserve Osmosis baru untuk pemenuhan kebutuhan air bersih warga pulau panggang yang akan dikerjasamakan oleh Swasta sebagai salah satu bentuk CSR.

4. Dari hasil perhitungan, kebutuhan yang paling tinggi kepentinganya adalah kebutuhan Air dimana kapasitas RO saat ini masih belum memenuhi sehingga harga air bersih masih tinggi.

Adapun saran yang dapat diberikan oleh Tim terkait dengan pelaksanaan PKM ini adalah:

1. Diperlukan in-depth interview dengan Dinas terkait untuk dapat menghitung detil kebutuhan utilitas terkait dengan rencana pengembangan hunian baru di pulau panggang.

\section{ACKNOWLEDGEMENT}

Tim Program Pengabdian Kepada Masyarakat (PKM) Jurusan Perencanaan Wilayah dan Kota Konsentrasi Real Estat ingin menyampaikan terimakasih kepada pihak yang telah mendukung program ini, diantaranya adalah:

1. Universitas Tarumanagara, khususnya Direktorat Penelitian dan Pengabdian Kepada Masyarakat (DPPKM) yang telah memberikan hibah program PKM tahun 2017/2018.

2. Ikatan Alumni Magister Teknik Perencanaan Kota Universitas Tarumanagara yang telah mencetuskan dan mengajak pelaksanaan kegiatan PKM ini.

3. Program Studi S1 Arsitektur sebagai pendukung tim dalam melakukan visualisasi dari konsep maupun master plan.

4. Pemerintah Kabupaten Administrasi Kepulauan Seribu yang telah menjadi mitra dalam Program Pengabdian Kepada Masyarakat Program Studi PWK - RE tahun 2017.

5. Community for Maritime Studies Indonesia (CMSI) selaku mitra dalam Program Pengabdian Kepada Masyarakat PS. PWK - RE tahun 2017.

6. Kementerian terkait (Kementerian Lingkungan Hidup dan Kehutanan, Kementerian Kelautan dan Perikanan, Kementerian Perhubungan Laut) yang telah memberikan masukan yang sangat berharga untuk kelancaran pelaksanaan PKM ini.

7. Bapak Lurah beserta jajaran Kelurahan Pulau Panggang yang telah membantu dalam pelaksanaan Survei Lapangan.

8. Masyarakat Pulau Panggang yang telah membantu dan bekerjasama dalam pelaksanaan Program Pengabdian Kepada Masyarakat Jurusan PWK - RE tahun 2017.

9. Ikatan Mahasiswa Planologi Universitas Tarumanagara (IMAPLANTA) yang telah membantu dalam pelaksanaan survei lapangan.

\section{REFERENSI}

Agrawal, P. 1999. Urban land consolidation: a review of policy and procedures in Indonesia and other Asian countries. GeoJournal 19: 311-322.

Bass, Stephen, Barry Dalal-Clayton (1995) Small Island States and Sustainable Development: Strategic Issues and Experience. Environmental Planning Issues. London.

Carlsen, Richard, Richard Butler (2011) Island Tourism: the Sustainable Perspective. CAB International. Cambridge.

Garrod, Brian, Julie. C. Wilson (2003) Marine Ecotourism: Issues and Experiences. Channel View Publications. Clevedon.

Kesuma, Meyriana (2006) Studi Revitalisasi Permukiman di Pulau Panggang, Kabupaten Kepulauan Seribu. Universitas Tarumanagara. DKI Jakarta.

Lim, Charles C. Chris Cooper (2009) Beyond Sustainability: Optimizing Island Tourism Development. International Journal of Tourism Research 11, 89-103. 